\title{
BUDIDAYA ORGANIK KEDELAI PADA SISTEM AGROFORESTRI MENGGUNAKAN PUPUK HAYATI
}

\author{
Steviana Baity ${ }^{1)}$, Djoko Purnomo ${ }^{2)}$ dan Triyono D.S. ${ }^{2)}$ \\ ${ }^{1)}$ Mahasiswa Program Studi Agroteknologi Fakultas Pertanian UNS \\ ${ }^{2)}$ Program Studi Agroteknologi Fakultas Pertanian UNS \\ Email: djpuruns@gmail.com
}

\begin{abstract}
Organic cultivation in egroforestry system by biofertilizer potentialy conducted for soybean. Soybean cultivation in agroforestry system there are several limitations but it have to effort since the area of ideal land decreasing year by year. The aim of the research by experiment method is increasing yield of soybean by organic cultivation in agrofrestry system either quality or quantity. The experiment design is randomized block design (RBD) with two factor trearments. The first factor are kinds of variety (Grobogan and Local) as mainplot and the second one are biofertilizer duration (no biofertilizer as control, 4, 5, 6, 7 weeks applies ones a week). So there are 10 combination treatments and replicated three times for each of them.
\end{abstract}

Keywords: Agroforestry, Biofertilizer, Soybean

\section{PENDAHULUAN}

Kedelai merupakan bahan pangan penting ketiga di Indonesia (setelah padi dan jagung), antara lain digunakan sebagai bahan baku pembuatan tempe, tahu, susu kedelai, dan pakan ternak, sehingga kebutuhan semakin meningkat seiring dengan pertambahan penduduk. Indonesia telah mampu menghasilkan kedelai 800 ribu ton per tahun, namun dengan rata-rata konsumsi kedelai per kapita sebesar 8,12 kg (Sudaryanto dan Swastika 2007), kebutuhan kedelai nasional mencapai 2,5 juta ton, sehingga impor masih 1,5 sampai 1,8 juta ton per tahun (Departemen Pertanian 2003). Salah satu hambatan peningkatan produksi kedelai dalam negeri adalah ketersediaan lahan. Untuk itu suatu alternatif adalah melalui penanaman dalam sistem agroforestri (Purnomo dan Sitompul 2005) meskipun kendala masih ada terutama cahaya bagi tanaman (Purnomo et al. 2013) dan teknologi pemupukan yang mengacu pada pertanian berkelanjutan dan keamanan pangan (Utomo 2010). Sebagai lahan budidaya sistem agroforestri dapat mencegah degradasi tanah sebagai akibat dari eksploitasi hutan (Mayrowani dan Ashari 2011) dan mewujudkan budidaya tanaman sehat (Hairiah 2003).

Untuk mencapai keamanan pangan dan pertanian sehat potensial dilakukan melalui sistem agroforestri dengan budidaya organik menggunakan pupuk hayati. Pupuk hayati sudah banyak diproduksi seperti nitragin
(Simanungkalit et al. 2006), biakan Azospirilium brasilense, Azospirilium lipoferum, dan Azospirilium amazonense (Sutanto 2002), powder yang mengandung Azotobacter sp., Azospirillum sp., Lactobasillus sp., Bacillus sp., Aspergillus $s p$., Trichoderma $s p$. yang dilengkapi: unsur makro dan mikro, senyawa bioaktif, hormon pertumbuhan, vitamin, dan anti hama hayati. Pupuk yang dikemas dalam bentuk powder memiliki keunggulan antara lain: daya hidup mikrobia lebih tinggi dengan populasi tidak kurang dari sejuta koloni per gram produk seperti persyaratan, tingkat kontaminasi rendah, dan umur simpan lebih lama (2-3 tahun) pada suhu ruang.

Sistem agroforestri dan penggunaan pupuk hayati dalam budidaya tanaman memerlukan informasi lebih luas mengingat kemungkinan terjadi imobilisasi hara terutama $\mathrm{N}$ oleh mikroorganisme tanah. Pupuk hayati berpotensi meningkatkan fiksasi $\mathrm{N}$ bebas, meningkatkan kelarutan $\mathrm{P}$, meningkatkan pengikatan $\mathrm{K}$, mengefektifkan penyerapan nutrisi tanah, meningkatkan kesuburan tanah dan memacu pertumbuhan vegetatif dan generatif pada tanaman, memperbaiki sifat fisik, kimia, dan biologi tanah dan mendorong pertumbuhan akar, membantu menjaga kelembaban tanah, meningkatkan pertumbuhan anakan, kualitas bunga, buah dan umbi, memperkuat ketahanan terhadap hama dan penyakit tanaman serta melindungi tanaman dari infeksi patogen akar. Penelitian 
untuk menjawab pertanyaan: apakah varietas Grobogan sesuai dengan sistem agroforestri Gunung Gajah, dapatkah pupuk hayati meningkatkan hasil kedelai pada sistem agroforestri Gunung Gajah dan bagaimana teknologi pemberiannya, serta adakah interaksi antara varietas dan pupuk hayati.

\section{METODE PENELITIAN}

Penelitian menggunakan metode percobaan dilaksanakan pada bulan April sampai dengan Agustus 2013 di Desa Gunung Gajah, Kecamatan Cawas, Kabupaten Klaten yang terletak pada $7^{\circ} 46^{\prime} 7,2^{\prime \prime} \mathrm{LS}$ dan $110^{\circ} 39^{\prime}$ $34,5^{\prime \prime}$ BT dan tinggi tempat $208 \mathrm{~m}$ dpl. serta jenis tanah litosol. Rancangan percobaan adalah rancangan acak kelompok (RAK) petak terpisah (split plot). Faktor pertama adalah varietas (Grobogan dan Lokal) sebagai petak utama (mainplot), dan faktor kedua adalah durasi pemberian pupuk hayati ( 0 sebagai kontrol dan 4, 5, 6, serta 7 minggu, diberikan setiap minggu) sebagai anak petak (sub plot), sehingga diperoleh 8 (delapan) kombinasi perlakuan, setiap kombinasi diulang 3 (tiga) kali. Sebelum penanaman dilakukan analisis tanah dan pupuk kandang tentang kandungan $\mathrm{N}, \mathrm{P}, \mathrm{K}, \mathrm{pH}$, dan bahan organik (BO).

Tanah diolah menggunakan cangkul, sebagai satuan percobaan dibuat petak berukuran 200 x $120 \mathrm{~cm}$. Penanaman sebanyak 4 biji setiap lubang tanam (dibuat dengan tugal) berjarak $20 \times 20 \mathrm{~cm}$, lubang kemudian ditutup dengan pupuk kandang dosis sekitar 8 ton per ha sebagai pupuk dasar dan starter pupuk hayati. Setelah tanaman berumur 14 hari diperjarang menjadi 2 tanaman per lubang. Pemberian pupuk hayati konsentrasi $50 \mathrm{~g}$ per 151 air dengan cara menyiramkan pada tanah. Pemeliharaan berupa penyiangan (setiap minggu), pengairan dengan sprayer (setiap tiga hari jika tidak turun hujan), dan pengendalian pengganggu (saat umur 45 hari menggunakan pestisida hayati).

Variabel penelitian berupa: kondisi cahaya (menggunakan lux meter), sifat tanah (kelembaban dengan higrometer Sauna, $\mathrm{pH}$ dengan $\mathrm{pH}$ meter, $\mathrm{N}$ tersedia dengan metode Kjeildahl, $\mathrm{P}$ dengan metode Bray, $\mathrm{K}$ tersedia, $\mathrm{C}$ organik, dan KTK), pertumbuhan vegetatif yang diamati secara destruktif pada umur 15 , 30, dan 45 hari sehingga diperoleh bobot biomassa (akar, batang, dan daun) yang dipergunakan untuk menghitung Indeks Luas
Daun (ILD), Luas Daun Spesifik (LDS), Harga Satuan Daun (HSD), dan Laju Pertumbuhan Absolut (LPA), pertumbuhan generatif, antara lain: jumlah dan berat polong isi dan hampa, bobot seratus biji, bobot biji, dan indeks panen. Data yang diperoleh melalui analisis ragam diperoleh uji $\mathrm{F}$ taraf 0,05 , jika berbeda nyata dilanjutkan dengan uji jarak berganda Duncan (Duncan Multiple Range Test/DMRT) dan uji korelasi.

\section{HASIL DAN PEMBAHASAN}

\section{Kondisi air dan tanah}

Kawasan agroforestri tempat penelitian memiliki curah hujan 141,43 mm per tahun, tidak tersedia sarana irigasi sehingga merupakan lahan tadah hujan. Kawasan berupa perbukitan (kemiringan 25-30\%), dengan kandungan bahan organik 0,925\% (sangat rendah), kadar N, P, dan K-tersedia masing-masing $0,06 \%$ (rendah), 4 ppm (rendah), dan 0,04 me $\mathrm{m}^{-100 \mathrm{~g}}$ (rendah), sehingga tingkat kesuburan termasuk kategori rendah. Agregasi tanah litosol belum optimum menandakan bahwa proses pedogenesis tanah belum lanjut. Ini ditunjukkan oleh kelas tekstur geluh berdebu (Silty Loamy), kadar C organik dan bahan organik rendah, persentase fraksi klei dan bahan organik juga rendah berakibat pada proses sementasi agregat tanah rendah. Kondisi tersebut mengakibatkan keadaan hidrologi daerah ini masuk dalam kategori kritis (Purnomo et al. 2012).

\section{Cahaya dan pertumbuhan tanaman}

Cahaya sebagai faktor penting bagi tanaman tergantung pada karakter tajuk pohon di agroforestri (Purnomo et al. 2013). Cahaya diterima oleh tajuk tanaman kedelai hanya sekitar 9,42\% dari 49000 lux. Selama pertumbuhan tanaman kedelai mengintersep cahaya sesuai dengan durasi pemupukan. Kedelai kontrol (tidak dipupuk) berumur 15, 30, dan 45 hari setelah tanam (hst) mengintersep cahaya sebesar 23,32 , dan $42 \%$, dipupuk selama 4 minggu mengintersep 35 , 47, dan 51\%, dipupuk selama 5 minggu mengintersep 38, 50, dan 64\%, dipupuk selama 6 minggu mengintersep 39, 48, dan $57 \%$, dan dipupuk selama 7 minggu mengintersep 39, 41, dan 49\%. Intersepsi cahaya ditentukan oleh struktur kanopi, sehingga menjadi indikator habitus tanaman yang tercermin pada karakter daun. Indeks luas daun (ILD) mencerminkan karakter daun 
di tanah tempat tanaman tumbuh. Tanaman mengintersep cahaya 50, 90, dan 95\% menjadi indikator ILD sebesar 1,0, 3,3, dan 4,3 (Sinclair and Gardner, 1998). Ini berarti bahwa ILD kedelai di penelitian ini hanya sekitar 1,0 sampai 2,0 yang menandakan pertumbuhan tidak optimum karena cahaya bagi tanaman sangat rendah (hanya 9,42\%). Bahkan ILD dari hasil pengukuran paling tinggi hanya 0,8 sehingga jauh dari ILD tanaman pertanian optimum 3-5 (Sitompul dan Guritno, 1995). Pemberian pupuk organik meningkatkan pertumbuhan kedelai (berdasarkan intersepsi cahaya) dan mencapai optimum dengan pemberian sebanyak 5 kali (pemberian setiap minggu) selama 5 minggu. Ini dapat dijelaskan bahwa efektifitas pemupukan melalui daun pada kedelai terjadi pada saat menjelang pertumbuhan konstan. Stadia vegetatif kedelai berlangsung sejak tanaman ditanam sampai umur 5 minggu atau 35 hst (Suharto, 2010).

Pertumbuhan tanaman yang mencerminkan kinerja tanaman direfleksikan dalam bentuk biomassa. Sejalan dengan dengan intersepsi cahaya di pembahasan yang dapat mencerminkan pertumbuhan terutama daun. Daun melakukan fotosintesis menghasilkan karbohidrat yang sebagian terakumulasi sebagai bahan kering dinyatakan dalam bobot biomassa. Partisi fotosintat ketiga arah yaitu menjadi bahan kering (biomassa), sebagai senyawa antara, dan energi bagi pertumbuhan (Taiz and Zieger, 2010). Bobot biomassa kedelai kontrol sangat rendah (hanya berkisar 0,22 hingga 0,46 g per tanaman) sejak berumur 15 hingga 45 hst. Bobot biomassa tertinggi dicapai oleh tanaman yang dipupuk 5 kali (pemberian setiap minggu) selama 5 minggu. Bobot biomassa saat mencapai pertumbuhan maksimum (umur $30 \mathrm{hst}$ ) sebesar 2,94-3,71 g per tanaman hampir sama dengan kedelai penelitian Purnomo, dkk. (2011) pada tempat berdekatan, namun lebih rendah dibanding bobot biomassa tanaman dalam sistem agroforestri berbasis jati dan pinus sebesar 8-14 g rumpun ${ }^{-1}$ (dua tanaman) (Purnomo dan Sitompul, 2006). Cahaya rendah yang diterima oleh kedelai menjadi penyebab bobot biomassa rendah karena fotosintesis jauh dibawah optimum.
Pertumbuhan kedelai tidak dapat terlepas dari simbiosis tanaman dengan rhizobium yang tercermin dalam bintil akar. Tidak seperti penelitian di agroforestri berbasis jati (Purnomo, 2014) yang belum pernah ditanami legume (jumlah bintil akar efektif hanya 4,9 per tanaman), di sini jumlah bintil akar efektif relatif besar (sekitar 15 hingga 25 per tanaman), dan tertinggi juga pada tanaman yang dipupuk 5 kali (pemberian setiap minggu) selama 5 minggu. Ini berarti bahwa pertumbuhan dan perkembangan rhizobium berlangsung dengan baik. Pertumbuhan dan perkembangan rhizobium berlangsung baik karena tanah tempat menanam kedelai pernah ditanami kedelai, pemberian pupuk kandang sebesar 8 ton ha ${ }^{-1}$ menyediakan $\mathrm{N}$, dan efektiftitas pemberian pupuk hayati lewat daun.

\section{Komponen produksi dan produksi}

Kedelai membentuk bunga dan setelah terjadi penyerbukan maka terbentuk polong. Keberhasilan pengisian polong tercermin dalam jumlah dan berat polong (isi dan hampa). Jumlah polong isi varietas Grobogan $(21,60)$ lebih tinggi daripada Lokal $(17,33)$. Tanaman yang dengan pupuk hayati 5 kali (pemberian setiap minggu) selama 5 minggu mencapai polong isi per tanaman tertinggi $(32,33)$ dibanding dengan durasi pemupukan 4, 6, dan 7 minggu (masing-masing dengan jumlah polong 19,67, 24, 61, dan 17,0). Jumlah polong hampa, berat polong isi dan hampa, dan berat biji per tanaman menunjukkan tanggapan tanaman yang sama terhadap pemupukan (masing-masing optimum selama 5 minggu pemupukan). Korelasi diantara bobot biomassa, polong hampa, bobot polong isi, dan bobot biji per tanaman, ILD, dan jumlah bintil akar efektif sangat erat (masing-masing saling berkorelasi positif dengan nilai $r$ paling rendah 0,88 ). Analisis regresi menunjukkan durasi pemupukan menentukan bobot biomassa, polong hampa, bobot polong isi, dan bobot biji per tanaman, ILD, dan jumlah bintil akar efektif masing-masing dengan $\mathrm{R}^{2}$ paling rendah 0,7 sampai paling tinggi mendekati 1 (gambar 1). 


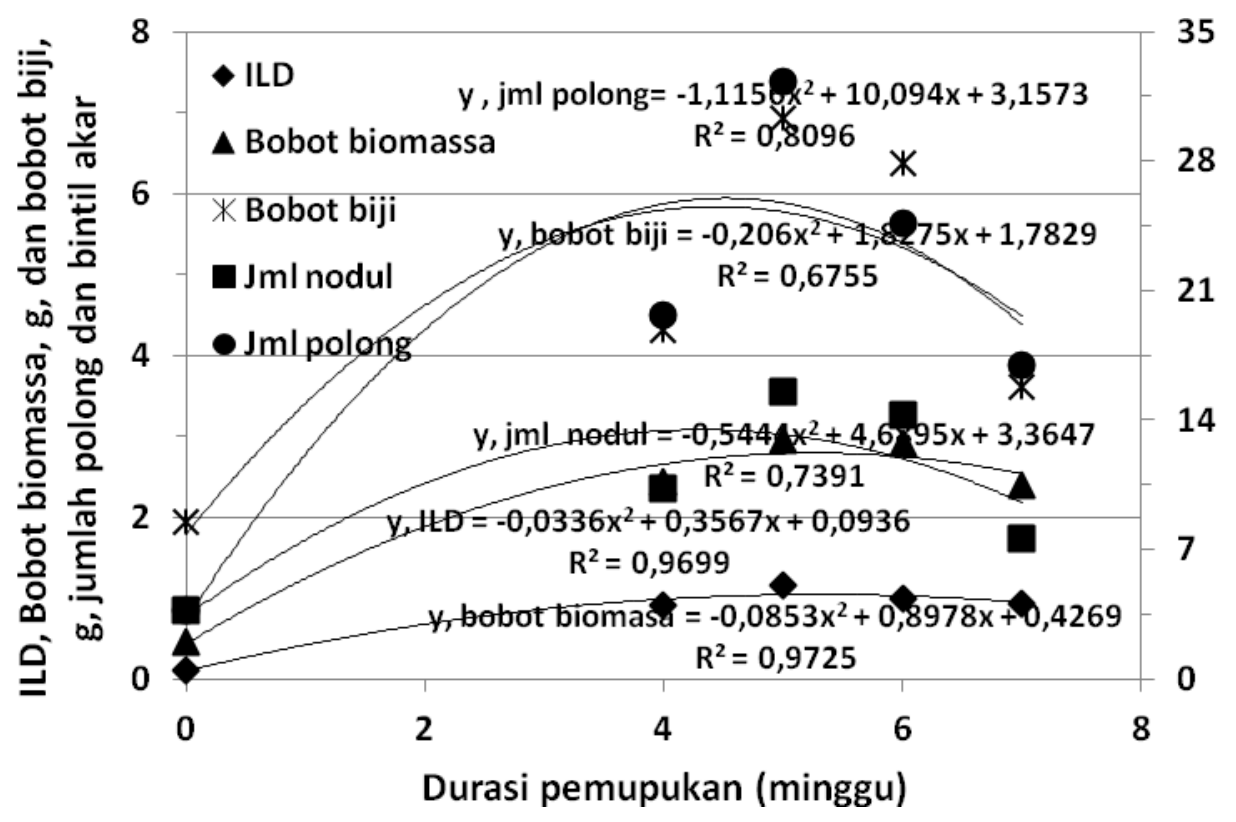

Gambar 1. Peran durasi pupuk hayati terhadap bobot biomassa, polong hampa, bobot polong isi, dan bobot biji per tanaman, ILD, dan jumlah bintil akar efektif; jml: jumlah, ILD: indeks luas daun).

Jumlah polong hampa pada penelitian ini relatif masih tinggi berarti dalam proses pengisian biji terjadi gangguan. Peran durasi pemupukan hayati terhadap jumlah polong hampa seperti variabel polong isi, sehingga semakin banyak polong isi juga semakin banyak polong hampa. Secara relatif polong hampa tanaman kontrol sebesar $49 \%$ menjadi berkurang bila dipupuk menjadi sekitar 38 hingga $47 \%$. Ini berarti suatu gangguan terhadap pengisian polong berarti besar yang kemungkinan besar adalah pertumbuhan yang kurang optimum karena cahaya rendah. Bobot biji tertinggi yang dicapai kedelai sebesar 6,93 g per tanaman yang setara dengan 1,7 ton $\mathrm{ha}^{-1}$ (jarak tanam $20 \times 20 \mathrm{~cm}$ ) pada tanaman yang dipupuk selama 5 minggu. Hasil ini relatif tinggi bila dibandingkan dengan rerata nasional sebesar 1,0 ton $\mathrm{ha}^{-1}$ dan penelitian budidaya organik menggunakan kompos di Wonogiri (0,6 ton ha ${ }^{-1}$ ) (Purnomo, 2014). Dengan jjumlah polong hampa yang relatif tinggi peningkatan hasil masih berpeluang besar dengan meningkatkan pengisian polong. Di Probolinggo (Jatim) kuantitas hasil kedelai ditentukan oleh jumlah polong, bobot 100 biji, dan jumlah biji, di Banyuwangi ditentukan oleh tinggi tanaman, jumlah polong, dan jumlah biji, sedang di Malang ditentukan oleh umur masak, jumlah polong, dan jumlah biji (Susanto dan Adie, (2006).

\section{KESIMPULAN}

Pupuk kandang ayam, sapi, dan kambing dapat digunakan dalam budidaya tanaman kedelai organik namun pupuk kandang sapi memiliki potensi tertinggi. Peran dosis dalam pertumbuhan tanaman relatif rendah, namun untuk memperbaiki kualitas buah diperlukan dosis 10-15 ton ha- ${ }^{-1}$. Penambahan larutan pupuk anorganik NPK atau penggunaan gibberellin dapat meningkatkan pertumbuhan dan kualitas buah kedelai (penggunaan giberelin lebih baik).

\section{UCAPAN TERIMAKASIH}

Terimakasih yang tak terhingga disampaikan kepada Nur 'Aisyah, Sri Ningsih, dan Ndaru Minanti, mahasiswa semester akhir mahasiswa Fakultas Pertanian UNS, Surakarta yang telah membantu dalam pelaksanaan penelitian ini.

\section{DAFTAR PUSTAKA}

Andrianto T.T dan Indarto 2004. Budidaya dan Analisis Usaha Tani: Kedelai, Kacang Hijau, Kacang Panjang. Absolut. Yogyakarta.

Black C and C Ong 2000. Utilization of light and water in tropical argiculture. 
Agricultural and Forest Meteorology 1004:25-47.

Budi G.P dan Oetami D.H 2008. kemapuan kompetisi beberapa varietas kedelai (Glycine max) terhadap gulma alangalang (Imperata cylindrica) dan teki (Cyperus rotundus). Artikel Ilmiah. Universitas Muhammadiyah Purwokerto.

Chusnia W, Tini S, Salamun 2012. Kajian pupuk hayati dalam meningkatkan pertumbuhan dan produksi tanaman kacang hijau (Vigna radiata L.) pada polybag. http://biologi.fst.unair.ac.id/wpcontent/uploads/2012/04/jurnal-

Wilda.pdf. Diakses pada tanggal 4 Juni 2013.

Departemen Pertanian. 2003. Database Departemen Pertanian. Jakarta.

Didik S, Kurniatun H, Nurheni W, Sunaryo, Meine VN 2003. Bahan ajaran agroforestri 4: peran agroforestri pada skala plot: analisis komponene agroforestri sebagai kunci keberhasilan atau kegagalan pemanfaatan lahan. Bogor: World Agroforestry Centre (ICRAF).

Kastono D 2005. Tanggapan pertumbuhan hasil kedelai hitam terhadap penggunaan pupuk organik dan biopestisida gulma siam (Chromolaena odorata). Ilmu Pertanian Vol. 12 No. 2, 2005: 103-116

Kemal 2001. Tentang budidaya pertanian: kedelai (Glycine max L). Jakarta: Menteri Riset dan Teknologi.

Kurniansyah D 2012. Produksi kedelai organik panen kering dari dua varietas kedelai dengan berbagai jenis pupuk organik. Laporan Penelitian. IPB Bogor.

Lukitasari M 2012. Pengaruh intensitas cahaya matahari terhadap pertumbuhan tanaman kedelai (Glycine max). IKIP PGRI Madiun.

Mayrowani H dan Ashari 2011. Pengembangan agroforestri untuk mendukung ketahanan pangan dan pemberdayaan petani sekitar hutan. Forum Penelitian Agro Ekonomi Vol. 29 No. 2, Desember 2011: 83-98.

Meirina T, Sri D, Sri H 2012. Produktivitas kedelai (Glycine $\max$ L. Merril var.
Lokon) yang diperlakukan dengan pupuk organik cair lengkap pada dosis dan waktu pemupukan yang berbeda. Laporan Penelitian. Jurusan Biologi Fakultas Matematika dan Ilmu Pengetahuan Alam Universitas Diponegoro.

Purnomo D dan S.M Sitompul 2005. Evaluasi potensi dan kendala pengembangan sistem agroforestri di Jawa Tengah. Habitat 4 (3): 197-207.

Purnomo D dan Sitompul S.M. 2006. Irradiasi pada sistem agroforestri berbasis jati dan pinus serta pengaruhnya terhadap pertumbuhan tanaman kedelai. Biodiversitas Vol. 7 No. 3: 251-255.

Purnomo D, Suryono, Trijono DS, Mth Sri Budiastuti, and Supriyadi. 2012. Varies litter containing tannin on agroforestry system as nitrification inhibitor for increasing nitrogen fertilizer effisiency for soybean. J. of Agriculture Sience and Technology B, 2 (2): 198-203.

Purnomo, D. dan Sitompul S.M., dan Budiastuti S. MTh. 2013. Solar radiation in agroforestry system. $J$. Of Agricultural Science and Technology B. Vol. 3 No. 8: 351-356.

Purnomo, D. 2014. Potensi budiadaya tanaman kedelai organik pada berbagai sistem agroforestri. Laporan Penelitian. Fak. Pertanian UNS.

Rosiana, N. 2013. Bobot Akar dan Bobot bintil akar efektif-non efektif kacang gude (Cajanus cajan) pada budidaya dengan pemupukan berbagai jenis sumber fosfat. Skripsi IKIP PGRI Semarang.

Rusmiati, Gani, dan Susilowati 2005. Pengaruh jarak tanam dan saat pemberian pupuk SP-36 terhadap pertumbuhan dan hasil tanaman kedelai (Glycie max (L). Merill) varietas anjasmoro. Jurnal Budidaya Pertanian Vol. 11 No. 2: hal 72-79.

Salisbury F.B dan Ross C.W 1992. Plant Physiology. Wadsworth Publishing. Company Belmont, California.

Simanungkalit, Didi AS, Rasti S, Diah S, Wiwik H 2006. Pupuk Organik dan Pupuk Hayati. Balai Besar Penelitian dan 
Pengembangan Sumberdaya Lahan Pertanian. Bogor.

Sumarsono 2008. Analisis kuantitatif pertumbuhan tanaman kedelai. Jurusan Nutrisi dan Makanan Ternak Fakultas Peternakan Universitas Diponegoro.

Susanto, G.W.A. dan M.M. Adie. 2006. Sidik lintas dan implikasinya pada seleksi kedelai. peningkatan produksi kacangkacangan dan umbi-umbian mendukung kemandirian pangan. Balai Penelitian dan Pengembangan Pertanian. Pusat Penelitian dan Pengembangan Tanaman Pangan Departemen Pertanian. Bogor. 914.

Sutanto R 2002. Penerapan Pertanian Organik: Pemasyarakatan dan
Pengembangannya. Penerbit Kanisius. Yogyakarta.

Utomo WH 2010. Agroforestry: Hidup Layak Berkesinambungan pada Lahan Sempit. Prosiding Tekanan Penduduk, Degradasi Lingkungan dan Ketahanan Pangan. IPB Bogor.

Widianto, Kurniatun H, Didik S, Mustofa AS 2003. Bahan ajaran agroforestri 3: fungsi dan peran agroforestri. Bogor: World Agroforestry Centre (ICRAF).

Yulianti T 2010. Bahan organik: perannya dalam pengelolaan kesehatan tanah dan pengendalian patogen tular tanah menuju pertanian tembakau organik. Bul. Tan. Tembakau, Serat dan Minyak Industri 2(1), April 2. 